\title{
ANALYSIS OF THE IMPLEMENTATION OF LAW IN EVERY LEVEL OF SOCIETY IN INDONESIA
}

\author{
Dany Try Hutama Hutabarat ${ }^{1}$, Agus Salam ${ }^{2}$, Ahmad Zuwandana ${ }^{3}$, Chairanda Al Azmi ${ }^{4}$, \\ Chandra Ridho Wijaya ${ }^{5}$, Darnita ${ }^{6}$, Ira Tania ${ }^{7}$, Lili Kahirina Azhari Lubis ${ }^{8}$, Muhammad Aldi \\ Prayuda Sitorus ${ }^{9}$, Robiatul Adawiyah ${ }^{10}$, Rizky Sinaga ${ }^{11}$ \\ $1-11$ \\ Fakultas Hukum Universitas Asahan \\ Jln. Jendral Ahmad Yani, Kisaran Naga, Asahan, Sumatera Utara \\ E-mail: ${ }^{1)}$ danytryhutamahutabarat@gmail.com
}

\begin{abstract}
Social stratification is a system in the social order that divides individuals into social classes. Finally, the social class will differentiate both the level and the rights and obligations of each individual in the class. The basis and core of a social stratification system is that there is an imbalance in the acquisition of rights and obligations, as well as responsibilities, between each individual and group in a series of social systems. The purpose of this research is to examine how law is applied at every level of society in Indonesia. This article was written using a qualitative technique, and it is designed to provide theoretical and practical usefulness to the community. According to the discussion, a social stratification system is one in which there is a distinction between one class or groups in standardized classes. Furthermore, there is evidence that there is a disparity between class stratification and law enforcement in Indonesia. As a result, law enforcement should be carried out in line with the applicable laws that have been jointly agreed upon in order to avoid creating a new long-term problems.
\end{abstract}

Keywords: Social Stratification, Law Implementation, Law Enforcement, Inequalities

\section{INTRODUCTION}

Law is both a tool and a function that can be used to bring about peace and tranquillity in a community, and it can bring about benefits that can be felt by people at all levels of society. A tight tie exists between law and society due to the fact that law is derived from culture and may be found in the habits that exist within a society. It is possible to find a variety of facts and events in the community itself that illustrate how the systems that govern the community's daily activity might be organized and developed from one another.

Social interaction is a phenomenon that affects all humans at some point in their evolution as social creatures, and hence cannot be avoided by them. After some time, social interaction will begin to play a role in the establishment of a group system in society, and it will eventually become one of the variables influencing the formation of a group system. In general, people in Indonesia are divided into a number of different categories. First, horizontally, which is referred to as differentiation, followed by vertically, which is referred to as social stratification.

The term stratification comes from the words strata and stratum which means layers. Therefore, social stratification is often translated as stratification of society (Maunah, 2015). Social stratification is defined as a system that distinguishes between individuals or groups in society, by placing each different social class hierarchically and giving different rights 
and obligations (Maunah, 2015). Additionally, this system distinguishes one class or group from another in stratified classes that will subsequently be divided into high-, middle-, and low-class groups (Maunah, 2015).

The fundamentals and essence of a system of social stratification is that each individual and group in a succession of social systems has an imbalance in attaining rights and obligations, as well as responsibilities. Individuals are classified into various classes depending on the qualities of power, privilese, and prestige in a higher hierarchical level based on a specific social system (Robert \& Robert, 1998). As a result of current society's unequally constructed power structures and the enormous number of people who create their own identities through social interaction, terms like social stratification, class disparity, and social exclusion are frequently used interchangeably (Arianto, 2010). Because of social inequality coming from a lack of social justice in the process of developing social stratification in society, whether consciously or unconsciously, a law will eventually be created that will apply in society.

Based on classical social theories, many studies have empirically examined its determinants and consequences of social class and inequality (Guo et al., 2018). The field's multidisciplinary knowledge is both diverse and insightful, as well as fragmented and heterogeneous. A detailed map of this increasingly complicated terrain is urgently needed to assist researchers and students in conducting efficient and successful literature reviews. As a result, there are problem formulations at the heart of this paper's discussion, such as: What are the differences in the application of law to the lower, middle, and upper social classes? and How can injustice in the application of law be avoided in every social class in society?

\section{RESEARCH METHOD}

The writing of this article employs a qualitative approach, which is believed to provide a benefit to the community on both a theoretical and practical level. Meanwhile, the data was collected through previous literature study.

\section{RESULT AND DISCUSSION}

\subsection{Application of Law to the Lower, Middle, and High Social Class}

According to the discussions that have taken place, the law is genuinely formulated with the goal of regulating the behavior and acts of every human being and achieving justice, benefit, and certainty in the jurisdiction in which the law is implemented. Additionally, the law gives universal benefits, specifically how to foster community peace and tranquillity that may be felt at all levels of society (Haryanti, 2014).

Law is inextricably linked to humans and all of their actions, including social interaction. In essence, humans are the parties as subjects who create the law, and they are also the ones who may benefit from and use the law in daily life. In Indonesia, several laws still represent uncertainty or have not been able to fully meet the objectives of the law's application (Wignjosoebroto, 2008).

In terms of upholding the law, the law is still on the verge of meeting society's expectations. Where is one of the frequently heard idioms that the law is "blunt upwards but sharp downwards". This is a reflection of the lower social classes' inability to find justice, 


\section{POLICY, LAW, NOTARY AND REGULATORY ISSUES (POLRI) \\ VOLUME 1 ISSUE 2 (2022)}

while the higher social classes often receive special privileges. Where one might enter this strata or top layer since they possess a number of useful and appreciated characteristics in society (Maunah, 2015). As a result, this serves as further proof that Indonesian law enforcement and socioeconomic stratification may not align.

One facet of law that protects goods and one's legal interests is the law. The issue here is that the law appears to be incapable of protecting the legal rights of those from lower socioeconomic classes. Although persons from lower social classes are frequently associated with people who do not share the same interests as people from higher social classes, the law should defend everyone's social class interests equally. For example, during the Covid-19 Pandemic, someone who plainly avoids or is missing from the obligation to self-quarantine receives a punishment that, upon evaluation, is not in conformity with the punishment that should be received. This is definitely not the same as policing a slew of street vendors who aren't following health regulations. Of course, the fines levied on self-quarantine violators are significantly higher in terms of quantity than those imposed on street vendors. However, in terms of quality, it should be taken into account when judging the quality of the law in applying the law to all socioeconomic classes in society, where the violation committed by the violator is merely a personal mistake, while the street vendor has an economic motivation.

\subsection{Prevention of Injustice in the Application of Law in Every Social Class in Society}

When dealing with various legal problems that arise throughout the country, it frequently becomes a topic of public debate because judicial rulings are thought to disregard the ideals of justice that should be felt by the community and justice seekers. Until now, the Indonesian legal system has been thought to fall short of properly reflecting true justice values. Justice seems to be a "expensive item" that society cannot afford (Rosaliza, 2017).

In social life, justice is defined as the allocation and preservation of human interests. Humans are known to exist in society in order to safeguard their interests and fulfill their needs, both of which can only be met if humans live side by side in social life (Widowati, 2013).

There are several factors that determine the running of order in a society (Rahardjo, 2010), namely the first structure, the second substance (the substance is composed of substantive rules and rules about how institutions should be have) and the last is legal culture. Based on these factors, the orientation is how the law is applied in society and public awareness of a rule needs to be increased (Haryanti, 2014).

There are two types of law in society: passive and active. The extent to which the law adapts to society demonstrates the law's passive nature. While active law refers to the extent to which the law can influence society's dynamics toward a desired transformation. As a result, the law serves as a tool for social transformation (a tool of social engineering) (Ali, 2002).

According to Effendi et al. (1991) the law will be carried out properly if two legal functions are implemented in people's lives, these functions are:

a) Its passive function is only to maintain the status quo. This function is called "Means of social control." 
b) Its active function is capable of overhauling the existing order towards a desired state. This function is known as "Law is a tool of social engineering", or the function of law as a tool of social engineering.

Furthermore, as stated by Marcus Tullius Cicero (106-43 SM) "ubi societas ibi ius" which means that where there is society there is law. In terms of society, it is always changing and developing (dynamic) while the law functions to control social life through determining what individuals in society should do and what they should not do (Chandra \& Widowati, 2006).

Therefore, law enforcement should be carried out in accordance with the applicable laws, which have been mutually agreed upon so as not to cause a new, prolonged problem. The law is enforced, and anyone who violates the sanctions will get strict and coercive. The law is applied indiscriminately, every community, both from the lower middle class and the upper class, must get the same treatment in the eyes of the law. The law is upheld, so that legal values will have a place for the public. In addition, there is a need for both transparency and supervision by the government regarding the operation of the law and the law enforcement process in Indonesia. Indeed, if there is no legal system that meets the needs of the community, a pattern of distrust between the community and legal institutions will develop in Indonesia, which will, of course, have an influence on the country's long-term viability and efficiency of operation.

\section{CONCLUSION}

The conclusions from the discussion described above are:

1. The social stratification system is a system in which there is a difference between one class or group in stratified classes with later being separated into high, middle, or low class groups.

2. There is a gap between social stratification and law enforcement in Indonesia. Therefore, law enforcement should be carried out in accordance with the applicable laws, which have been mutually agreed upon so as not to cause a new, prolonged problem. The law is enforced, whoever violates the sanctions will get firm and coercive.

\section{REFERENCES}

Ali, A. (2002). Menguak Tabir Hukum. PT. Toko Gunung Agung.

Arianto, H. (2010). Hukum Responsif dan Penegakan Hukum di Indonesia. Lex Jurnalica, $7(2), 18013$.

Chandra, A., \& Widowati, C. (2006). Laporan Penelitian Model Konstruksi Hukum Dalam Yurisprudensi (Studi Kasus Putusan Mahkamah Agung No. 3199K/Pdt/1986).

Effendi, R., Ali, A., \& Lolo, P. A. (1991). Teori Hukum. Hasanudin University Press.

Guo, L., Li, S., Lu, R., Yin, L., Gorson-Deruel, A., \& King, L. (2018). The research topic landscape in the literature of social class and inequality. PloS One, 13(7), e0199510.

Haryanti, T. (2014). Hukum dan Masyarakat. Jurnal: Tahkim. 
Maunah, B. (2015). Stratifikasi Sosial Dan Perjuangan Kelas Dalam Perspektif Sosiologi Pendidikan. Ta'allum: Jurnal Pendidikan Islam, 3(1), 19-38.

Robert, M. Z., \& Robert, L. (1998). Teori Sosiologi Mikro dan Makro Jilid 1. Jakarta: Rineka Cipta.

Rosaliza, M. (2017). Lapisan Sosial Masyarakat Perkotaan. Jurnal Ilmu Budaya, 13(2), 93110.

Widowati, C. (2013). Hukum Sebagai Norma Sosial Memiliki Sifat Mewajibkan. ADIL: Jurnal Hukum, 4(1), 150-167.

Wignjosoebroto, S. (2008). Hukum dalam masyarakat: perkembangan dan masalah. 
